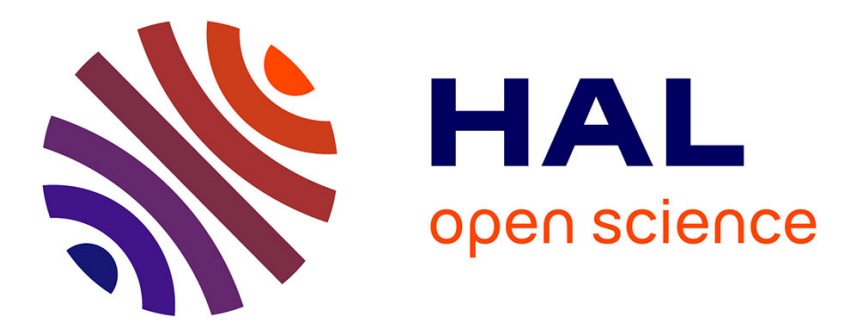

\title{
Modeling of Sewage Sludge Flow in a Continuous Paddle Dryer
}

Mathieu Milhé, Christophe Charlou, Martial Sauceau, Patricia Arlabosse

\section{To cite this version:}

Mathieu Milhé, Christophe Charlou, Martial Sauceau, Patricia Arlabosse. Modeling of Sewage Sludge Flow in a Continuous Paddle Dryer. Drying Technology, 2015, 33 (9), pp.1061-1067. 10.1080/07373937.2014.982252 . hal-01168605

\section{HAL Id: hal-01168605 https://imt-mines-albi.hal.science/hal-01168605}

Submitted on 20 Oct 2016

HAL is a multi-disciplinary open access archive for the deposit and dissemination of scientific research documents, whether they are published or not. The documents may come from teaching and research institutions in France or abroad, or from public or private research centers.
L'archive ouverte pluridisciplinaire HAL, est destinée au dépôt et à la diffusion de documents scientifiques de niveau recherche, publiés ou non, émanant des établissements d'enseignement et de recherche français ou étrangers, des laboratoires publics ou privés. 
This article was downloaded by: [Ecole des Mines D'Albi]

On: 20 January 2015, At: 01:25

Publisher: Taylor \& Francis

Informa Ltd Registered in England and Wales Registered Number: 1072954 Registered office: Mortimer House, 37-41 Mortimer Street, London W1T 3J H, UK

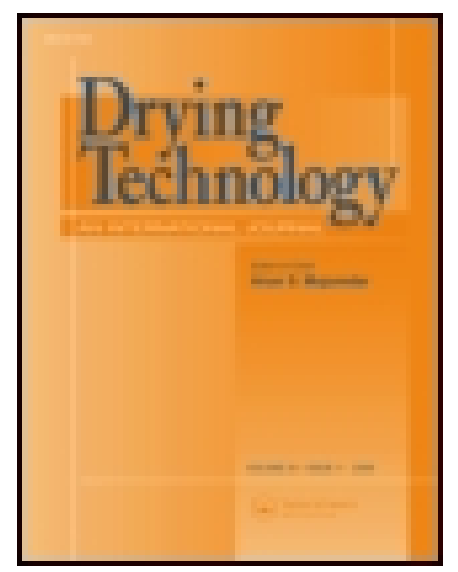

\title{
Drying Technology: An International J ournal
}

Publication details, including instructions for authors and subscription information:

http:// www.tandfonline.com/loi/ldrt20

\section{Modeling of Sewage Sludge Flow in a Continuous Paddle Dryer}

\author{
M. Milhé ${ }^{a}$, C. Charlou ${ }^{a}$, M. Sauceau ${ }^{a} \&$ P. Arlabosse $^{a}$ \\ a Université de Toulouse; Mines Albi; CNRS; Centre RAPSODEE, Albi, France \\ Accepted author version posted online: 01 Dec 2014.
}

\section{CrossMark}

Click for updates

To cite this article: M. Milhé, C. Charlou, M. Sauceau \& P. Arlabosse (2014): Modeling of Sewage Sludge Flow in a Continuous Paddle Dryer, Drying Technology: An International J ournal, DOI: 10.1080/ 07373937.2014.982252

To link to this article: http:// dx.doi.org/ 10.1080/07373937.2014.982252

Disclaimer: This is a version of an unedited manuscript that has been accepted for publication. As a service to authors and researchers we are providing this version of the accepted manuscript (AM). Copyediting, typesetting, and review of the resulting proof will be undertaken on this manuscript before final publication of the Version of Record (VoR). During production and pre-press, errors may be discovered which could affect the content, and all legal disclaimers that apply to the journal relate to this version also.

\section{PLEASE SCROLL DOWN FOR ARTICLE}

Taylor \& Francis makes every effort to ensure the accuracy of all the information (the "Content") contained in the publications on our platform. However, Taylor \& Francis, our agents, and our licensors make no representations or warranties whatsoever as to the accuracy, completeness, or suitability for any purpose of the Content. Any opinions and views expressed in this publication are the opinions and views of the authors, and are not the views of or endorsed by Taylor \& Francis. The accuracy of the Content should not be relied upon and should be independently verified with primary sources of information. Taylor and Francis shall not be liable for any losses, actions, claims, proceedings, demands, costs, expenses, damages, and other liabilities whatsoever or howsoever caused arising directly or indirectly in connection with, in relation to or arising out of the use of the Content.

This article may be used for research, teaching, and private study purposes. Any substantial or systematic reproduction, redistribution, reselling, loan, sub-licensing, systematic supply, or distribution in any form to anyone is expressly forbidden. Terms \& Conditions of access and use can be found at http:// www.tandfonline.com/page/terms-and-conditions 


\title{
MODELING OF SEWAGE SLUDGE FLOW IN A CONTINUOUS PADDLE DRYER
}

\author{
M. Milhé ${ }^{1}$, C. Charlou ${ }^{1}$, M. Sauceau ${ }^{1}$, P. Arlabosse ${ }^{1}$ \\ ${ }^{1}$ Université de Toulouse; Mines Albi; CNRS; Centre RAPSODEE, Albi, France \\ Corresponding Author to P. Arlabosse: E-mail: Patricia.Arlabosse@mines-albi.fr
}

\begin{abstract}
A model based on the theory of Markov chains has been developed to represent the residence time distribution (RTD) of municipal sewage sludge in a continuous paddle dryer. The flow of dry solids is described by a chain of $n$ perfectly mixed cells, $n$ corresponding to the number of paddles attached to the shaft. The transition probabilities between the cells are governed by two parameters: the parameter of internal recirculation, $R$, and the solids hold-up, $H u$. In the absence of available correlation, both parameters are identified by fitting the model to experimental RTD data. The model demonstrates its ability to describe the sludge flow in a continuous lab-scale paddle dryer. A sensitivity analysis highlights that $R$ is critical for the treatment uniformity while $H u$ controls the mean residence time and thus the final moisture content.
\end{abstract}

KEYWORDS: Stochastic approach, Markov Chains, Cells model, Residence time distribution, Experiment

\section{INTRODUCTION}

Sewage sludge management is an important issue for large urban areas. Considering their high organic content, municipal sewage sludge is a promising feedstock for Waste-to- 
Energy (WtE) processes. Incineration is by far the most common process but pyrolysis and gasification emerge ${ }^{[1-3]}$. Unfortunately, organic sludge has a high water content ${ }^{[4]}$ : it is usual to meet sludge with only 18 to $25 \%$ of solids after mechanical dewatering by centrifugation or belt filters. Higher solids contents (around 30 to 35\%) can be achieved with filter presses but their discontinuous operation makes them unsuited for large wastewater treatment plants (WWTP). These solids concentrations are too weak for an efficient WtE conversion ${ }^{[4]}$. Indeed, dry solids contents from $60 \%$ to $90 \%$ are expected for co-incineration with municipal solid wastes while more than $85 \%$ are needed for pyrolysis and gasification. As a consequence, drying is essential to increase the dry solids content prior to thermal valorization. Even if many technologies are available ${ }^{[4-7]}$, this operation remains an economical bottleneck. Paddle dryers offer several advantages such as high heat fluxes, low specific energy consumption and low exhaust volumes. Moreover, the design of the shafts is well adapted to overcome the sticky state and process the sludge up to complete drying without recycling dry matter upstream. However, in two thirds of the drying plants the dry solid content often exceeds $90 \%{ }^{[8]}$. In addition to the lost energy, this excessive drying causes troubles for handling and storage of the dried sludge, as well as safety problems ${ }^{[9]}$. Adjusting the solid content of the dried sludge to the valorization routes is essential to improve the sustainability of WtE conversion processes.

Until now, few efforts have been dedicated to experimental and numerical investigations on continuous paddle dryers for sludge treatment. Whereas tools to describe, and even predict, heat and mass transfers have been available for a few years ${ }^{[10-12]}$, sludge flow 
has been partly characterized very recently. According to Tazaki et al. ${ }^{[13]}$ and Charlou et al. ${ }^{[14]}$, the flow pattern is not a simple plug flow. Back mixing of the sludge occurs ${ }^{[13]}$, especially near the middle of the dryer where the sludge consistency is sticky. To our knowledge, the modeling of sludge flow has not been addressed in the literature yet. Sludge rheological behavior is complex ${ }^{[15-17]}$ and poorly documented for high dry solids contents $^{[15]}$. As a result, mechanistic approaches and computational fluid dynamics (CFD) modeling are out of reach for the time being. Chemical engineers use the concept of residence time distribution (RTD) to characterize flow patterns in a reactor ${ }^{[18,19]}$. The principle of RTD measurements is to inject an inert tracer into the reactor at some time $t=0$ and to measure the tracer concentration in the outlet stream as a function of time. The residence time distribution function, which describes in a quantitative manner how much time different fluid elements have spent in the reactor, is computed from the concentration-time curve. Based on these experimental data, a flow model can be proposed to predict the RTD in the reactor or the apparatus. Coupled with kinetic data, the average outlet concentration in a real reactor or apparatus can then be predicted. Many models are available to describe deviations from the ideal continuous stirred tank reactor (CSTR) or plug flow reactor (PFR) ${ }^{[20]}$. Cell models, mostly based on the theory of Markov chains ${ }^{[21]}$, present the advantage of describing the design of the apparatus, since the cell size can be conditioned by sections covering the paddles for instance. Markov chains proved to be efficient to model bulk particulate flow in a great variety of processes ${ }^{[22-25]}$. This approach has been widened to describe heat and mass transfers between stochastically moving particulate and gas flows ${ }^{[26,27]}$. In this paper, we assume that the agitated contact drying process is a Markov process and we propose a cell model, 
based on a 1D homogeneous Markov chain, to describe the flow of the anhydrous solids in a paddle dryer. Experimental RTD data are used to identify the two models parameters. A sensibility study of the model responses - the mean residence time and the variance of the RTD - to the variations of the model parameters is also undertaken to identify the most influential model parameters.

\section{MODEL DESCRIPTION}

\section{Physical Model And Modelling Assumptions}

In this study, a lab-scale continuous agitated contact dryer, designed and built in our institute (see Figure 1), is used as an example to build the physical model. A full description of the experimental set-up is available in Charlou et al. ${ }^{[14]}$. The main characteristics are summarized hereafter. The dryer consists of a U-shaped heated trough with one rotating shaft inside. Nineteen full wedge-shaped paddles are screwed onto the rotor and heated by conduction. In the current configuration, the paddles are regularly distributed along the shaft. Scrapers, formed to interact with the paddles and generate intense shearing, are positioned on the trough. The sludge is fed into one end of the trough and flows due to gravity, dryer slope and mechanical agitation to the opposite end, where the dry material is discharged. The sludge structure evolves from a fluid to a pasty and, then, to a particulate matter.

The principle of the Markov model is to represent the solids circulating in the dryer by a chain containing a finite number of cells. Let us divide the total length of the process into $n$ perfectly mixed cells of equal length and mass of dry matter. As we want to preserve a 
physical description of the process, $n$ is not an adjustable parameter of the model. In the following, we will assume that the number of active cells, $n$, is equal to the number of paddles. When a granular flow exists, we can assume that, in the vicinity of the paddle, part of granules will flow forward whereas the other part will stay in the vicinity of the paddle or will move backward. Thus, in the presence of recirculation phenomena, the cells must be connected by internal flows, which represent the circulation of the matter forward (from the current cell to the following one) and the recirculation in the opposite direction (from the current cell to the previous one). We will consider that only transitions between neighboring cells are possible between two successive observations of the system. At the end of the chain, a last cell $(n+1)$ must represent the collector of dried sludge particles located at the dryer outlet. This cell is called the absorbing cell. Of course, backward transition from the absorbing state is forbidden. The structure of the 1D chain is presented in Figure 2. We will investigate exclusively the steady state operation of the dryer.

\section{Mathematical Model}

Let us observe the state of the process at discrete moments of time $t_{m}=m * \Delta t$, where $\Delta t$ is the transition duration between two successive observations, and $m$ is the number of transitions. If we examine the evolution of any additive property $S$ (mass, for instance) of a flow, its distribution over the process length can be presented as a state vector $\boldsymbol{S}=S_{1} \quad S_{2} \quad S_{3} \quad \ldots \quad S_{n}{ }^{t}$. During $\Delta t$, the state $S_{i}$ in the $i$-th cell can change due to the amount of $S$ that comes from the other cells or that leaves the cell. Thus, the evolution of $S$ is controlled by a matrix of transition probabilities $\boldsymbol{P}$. $\Delta t$ has to be small enough so that 
only transitions between neighboring cells are possible. As a result, three probabilities can be considered: a probability of staying in the cell, $P_{i, i}$, a probability to move forward, $P_{i+1, i}$, and a probability to move backward, $P_{i-1, i}$. The matrix $\boldsymbol{P}\left(n+1 *_{n+1}\right)$, that contains all the possible transition probabilities corresponding to a transition time $\Delta t$, takes the form described by Eq.(1).

$$
\mathrm{P}=\left[\begin{array}{ccccccc}
\mathrm{P}_{1,1} & \mathrm{P}_{1,2} & \ldots & 0 & 0 & 0 & 0 \\
\mathrm{P}_{2,1} & \mathrm{P}_{2,2} & \ldots & 0 & 0 & 0 & 0 \\
0 & \mathrm{P}_{3,2} & \ldots & \mathrm{P}_{\mathrm{i}-1, \mathrm{i}} & 0 & 0 & 0 \\
\ldots & \ldots & \ldots & \mathrm{P}_{\mathrm{i}, \mathrm{i}} & \ldots & \ldots & \ldots \\
0 & 0 & 0 & \mathrm{P}_{\mathrm{i}+1, \mathrm{i}} & \ldots & \mathrm{P}_{\mathrm{n}-1, \mathrm{n}} & 0 \\
0 & 0 & 0 & 0 & \ldots & \mathrm{P}_{\mathrm{n}, \mathrm{n}} & 0 \\
0 & 0 & 0 & 0 & 0 & \mathrm{P}_{\mathrm{n}+1, \mathrm{n}} & \mathrm{P}_{\mathrm{n}+1, \mathrm{n}+1}
\end{array}\right]
$$

In steady state operation, the condition of mass conservation involves that the sum of all the elements in each column is equal to one. As the backward transition from the absorbing state is forbidden, $P_{n+1, n+1}=1$.

According to the stochastic motion of the particles, the throughput in a cell is not equal to the throughput in the dryer. The difference is taken into account by the recirculation coefficient $R$ which is defined as the ratio between the recirculated flow in each cell and the inflow rate (see Figure 2).

The geometrical residence time, $\tau_{c e l l}$, and the probabilities $P_{i, i}, P_{i+1, i}, P_{i-1, i}$ are defined in Table $1 . H u$ is the dry solids hold-up in each cell and $Q_{d s}$ is the dry solids throughput in the Markov chain. During the transition time $\Delta t$, the probability of staying in a cell is an 
exponential function of this time ${ }^{[24]}$. The matrix of transition probabilities $\boldsymbol{P}$ is constant since the model describes a steady-state operation. In Markovian language, the process is said linear and the Markov chain homogeneous. Moreover, we assume that $R$ and $H u$ do not vary along the cells in a first approach, since we cannot estimate experimentally the variation of these parameters. The evolution of the state vector for a transition $\Delta t$ is then described by the following formulas:

$$
\begin{aligned}
& \mathbf{S} \mathrm{t}+\Delta \mathrm{t}=\mathbf{P}^{*} \mathbf{S} \mathrm{t} \\
& \text { or } \\
& \mathbf{S} \mathrm{t}+\Delta \mathrm{t}=\mathbf{P}^{m} * \mathbf{S} \mathrm{t}=0
\end{aligned}
$$

\section{Numerical Model}

Using the RTD concept, the experimenter gets the concentration-time curve by injecting a tracer in a known concentration (or quantity) at the reactor inlet and analyzing this tracer concentration (or quantity) in the product at the outlet. Then he computes the RTD function, $E(t)$, which describes in a quantitative manner how much time different fluid elements have spent in the reactor. For a Dirac injection, i.e. instantaneous and not perturbing the flow, $E(t)$, also called the exit age distribution function, is given by Eq. (4), while its cumulative form $F(t)$ is given by Eq. (5):

$$
\begin{aligned}
& E t=\frac{\mathrm{C} t}{\int_{0}^{\infty} \mathrm{C} t d t} \\
& F t=\int_{0}^{\infty} E t d t
\end{aligned}
$$


Numerically, we can simulate the Dirac injection of a tracer in the system by using the following initial state vector, which means that at $\mathrm{t}=0$, a tracer of quantity 1 is injected in the first cell of the system:

$$
S \mathrm{t}=0=1 \quad 0 \quad 0 \quad \ldots 0^{t}
$$

$E(t)$ is calculated as the difference, between two successive transitions, of the tracer quantity reaching the absorbing cell as in Eq. (7), which corresponds to a discretized version of Eq. (4). $F(t)$ is given by the amount of tracer cumulated in the absorbing state (Eq. (8)):

$$
\begin{aligned}
& E t=S t_{n+1}-S t-\Delta t_{n+1} \\
& F t=S t_{n+1}
\end{aligned}
$$

Knowing $E(t)$, it is easy then to compute the mean residence time, $t_{s}$, the variance, $\sigma^{2}$, and the dimensionless variance, $\sigma_{D}^{2}$ :

$$
\begin{aligned}
& t_{s}=\int_{0}^{\infty} t \cdot E t d t \\
& \sigma^{2}=\int_{0}^{\infty} t-t_{s}^{2} E t d t \\
& \sigma_{D}^{2}=\left(\frac{\sigma}{t_{s}}\right)^{2}
\end{aligned}
$$


The model only depends on two parameters: the recirculation coefficient, $R$, and the ratio $\xi=H u / Q_{d s}$ between the dry solids hold-up and the dry solids throughput. Both parameters are a priori unknown. But, if we consider that usually the dry solids throughput $Q_{d s}$ is known, only the solids hold-up, $H u$ has to be identified. A third parameter, the transition duration, $\Delta t$, also appears in the mathematical model. Previously, we assumed that the transition duration, $\Delta t$, is small enough so that particles in a cell could be able to transit only to the neighboring cells. But the choice of $\Delta t$ is not straightforward. Moreover, only some scarce papers explain how the choice was made ${ }^{[22,}$ ${ }^{28]}$. Consequently, the influence of the transition duration on the mean residence time and the dimensionless variance was investigated numerically. The selection of $\Delta t$ has to be done by taking into account that the smaller $\Delta t$ the higher the model precision, but the higher the calculation time. Figure 3 illustrates the evolution of the standardized mean residence time and the standardized dimensionless variance according to the transition time for $R=1.9$ and $\xi=0.19 \mathrm{~h}$ or $R=4.6$ and $\xi=0.16 \mathrm{~h}$. The computed values were standardized by the values for the lowest transition duration, i.e. $\Delta t=0.5 \mathrm{~s}$. For $\Delta t>3.6 \mathrm{~s}$, the mean residence time and the standardized dimensionless variance strongly depend on the value of the transition duration. Below this threshold, they tend gradually towards a constant value and the exit age distribution function, $E(t)$, does not change anymore (see Figure 4). For $\Delta t=2 \mathrm{~s}$, both RTD characteristics are in the $99 \%$ confidence interval. To get a compromise between model precision and calculation time, we selected $\Delta t=2 \mathrm{~s}$.

In the following, the recirculation coefficient $R$ and the solids hold-up $H u$ are identified by fitting the model to the experimental RTD data using MATLAB ${ }^{\circledR}$ software. The 
fminsearch function (based on a Nelder-Mead algorithm) was used to minimize the least sum of squares of the difference between experimental and simulated $E(t)$. A threshold of $10^{-4}$ was set for the variation of the residue, $\Delta E$, between two successive iterations. In Eq. (9) the subscripts $\exp$ and $c a l$ stand for the experimental and corresponding calculated discrete values of $E(t)$ respectively.

$$
\Delta E=\sum E_{\text {exp }}-E_{c a l}{ }^{2}
$$

\title{
RESULTS AND DISCUSSION
}

\author{
Ability Of The Cells Model To Describe Sludge Flow In A Lab-Scale Paddle Dryer \\ Experiments were performed on the lab scale paddle dryer using the sewage sludge from \\ the municipal WWTP of Albi (France) as feedstock. The WWTP implements a \\ conventional extended aeration process, a nitrification/denitrification process, a \\ biological phosphorus removal and a mesophilic anaerobic digestion. The sludge was \\ sampled after centrifugation and stored at $4{ }^{\circ} \mathrm{C}$ in tight containers during a minimum of \\ $48 \mathrm{~h}$ before the experiments. Its dry basis initial moisture content was $3.7 \mathrm{~kg} / \mathrm{kg}$.
}

Drying experiments were performed at atmospheric pressure, with a dryer wall temperature set at $160{ }^{\circ} \mathrm{C}$ and with $1.1 \mathrm{~kg} / \mathrm{h}$ of superheated steam at $160{ }^{\circ} \mathrm{C}$ as sweeping gas. The dryer was titled of $3^{\circ}$ and the inlet mass flow rate was set at $2.5 \mathrm{~kg} / \mathrm{h}$ on a wet basis. When the steady state was reached, 3 successive pulse injections of tracers were performed at $1 \mathrm{~h}$ interval each. Partially dried sludge was sampled at the outlet at a frequency of $5 \mathrm{~min}$, dried at $105^{\circ} \mathrm{C}$ for $24 \mathrm{~h}$ and analyzed off-line using X-ray 
fluorescence spectroscopy (PANanlytical, Almelo, Netherlands), which give access to experimental $E(t)$ curves $^{[29]}$.

As mentioned before, the dry solids throughput $Q_{d s}$ is known indirectly, from the inlet mass flow rate and moisture content. Thus, only the recirculation coefficient, $R$, and the solids hold-up, $\mathrm{Hu}$, have to be identified in our model. Figure 5 illustrates the ability of the model to represent the experimental RTD function, $E(t)$, and its cumulative form $F(t)$ after the optimization described previously, for one of the three injections realized. For the experiments, the stirring speed was set to $28 \mathrm{rpm}$ (see Figure 5 a) and $14 \mathrm{rpm}$ (Figure $5 b)$ respectively. For both experiments, the model describes experimental data with a good accuracy.

The parameters from the experimental data and their mean values calculated after optimization of the three modeled RTD curves are reported in Table 2 for both experiments. Experimentally, the solids hold-up is obtained by weighing the total remaining dry sludge in the dryer at the end of an experiment. The experimental and optimized values of $H u$ are close in both cases, indicating that the optimization procedure does not end in unrealistic values of this physical parameter. Finally, we observe a slight difference between $R$ values obtained for both experiments, but this difference is not really significant with respect to the standard errors. Since both RTD curves have similar shapes in spite of these slight parameters differences, the respective influences of $R$ and $H u$ on model results should be studied before concluding on the effect of stirring speed on these parameters. For this reason, we proceeded to a sensitivity analysis of the model. 


\section{Sensitivity Analysis}

To clarify the influence of both parameters on the RTD, a numerical parametric study was performed in the range $0 \leq R \leq 20$ and $0.025 \leq \xi \leq 0.18 \mathrm{~h}$. Figures 6 and 7 emphasize the influence of $R$ and $\xi$ on the RTD curves while Figure 8 highlights the influence of both parameters on the mean residence time and the dimensionless variance. $R$ has little influence on the mean residence time. An increase of $R$ results in a strong enhancement of the dimensionless variance. As can be seen on Figure 6, the exit age distribution function spreads out when $R$ increases and the flow evolves from the ideal plug-flow $(R=0)$ to the one observed in an ideal continuous stirred tank reactor. From a practical point of view, it is essential to reduce back-mixing phenomena in paddle dryers $(R \rightarrow 0)$ to achieve a uniform drying, through the shaft retrofit for instance. On the contrary, $\xi$ has a strong influence on the mean residence time. The evolution is almost linear: the mean residence time increases by a factor 4.4 when $\xi$ is multiplied by 4.5 . Thus, the solids hold-up is the most critical parameter to control the moisture content at the dryer exit. For the time being, no correlation is available in the literature to predict the solids hold-up from the operating conditions.

\section{CONCLUSIONS}

A cell model, based on the theory of Markov chain, has been developed to describe sludge flow in a paddle dryer. To preserve a physical description of the process, the number of cells corresponds to the number of paddles fixed on the dryer shaft. The model is able to predict the residence time distribution, the mean residence time and the variance. Only transitions between neighboring cells are allowed between two successive 
observations of the system. The model only depends on two parameters: the recirculation coefficient and the volume of the cells, i.e. the solids hold-up in the dryer. The recirculation coefficient has an influence on the distribution width, and thus on the uniformity of the drying treatment. The solids hold-up in the dryer is critical for the mean residence time of solids in the dryer and the control of the outlet moisture content. We demonstrate the ability of the model to describe experimental RTD curves achieved on a lab-scale continuous paddle dryer. But, in the absence of correlation in the literature to predict the solids hold-up in the dryer, both parameters have to be identified by adjusting the model to the experimental data. The establishment of this correlation, for at least the lab scale process, is in progress. The extension of this model to predict moisture profile along the dryer, by coupling a heat and mass transfer model based on the penetration theory, is also investigated.

\section{ACKNOWLEDGMENT}

The authors would like to acknowledge Bernard AUDUC for kind technical assistance in the construction and development of the experimental set-up.

\section{NOMENCLATURE}

C Tracer concentration $\left(\mathrm{kg} \cdot \mathrm{kg}^{-1}\right)$

$E(t) \quad$ Exit age distribution function $\left(\mathrm{h}^{-1}\right)$

$F(t) \quad$ Cumulative function $(-)$

$m \quad$ Number of transition (-)

$Q_{d s} \quad$ Dry solids mass flow rate $\left(\mathrm{kg} . \mathrm{h}^{-1}\right)$ 
$H u \quad$ Dry solids hold-up (kg)

$n \quad$ number of active cells (-)

$\boldsymbol{P} \quad$ Matrix of transition probabilities (-)

$P_{j, i} \quad$ Probability to move from cell $\mathrm{i}$ to cell $\mathrm{j}(-)$

$R \quad$ Recirculation coefficient (-)

$S \quad$ State vector (-)

$t \quad$ Time (h)

$t_{s} \quad$ Mean residence time (h)

\section{Greek letters}

$\sigma^{2} \quad$ Variance (-)

$\sigma_{D}^{2} \quad$ Dimensionless variance (-)

$\tau_{\text {cell }} \quad$ Geometric residence time in a cell (h)

$\xi \quad$ Solids holdup to mass flow rate ratio (h)

$\Delta E \quad$ Minimization function (-)

$\Delta t \quad$ Transition time (s)

\section{Subscripts}

cell Cell of the Markov chain

D Dimensionless

$i \quad$ Cell number

$\exp$ Experimental value

cal Calculated value 


\section{REFERENCES}

1. Werther, J.; Ogada, T. Sewage sludge combustion. Progress in Energy 1999, 25(1), 55-116.

2. Manara, P.; Zabaniotou, A. Towards sewage sludge based biofuels via thermochemical conversion - A review. Renewable and Sustainable Energy Reviews 2012, 16(5), 2566-2582.

3. Fonts, I.; Gea, G.; Azuara, M.; Ãbrego, J.; Arauzo, J. Sewage sludge pyrolysis for liquid production: A review. Renewable and Sustainable Energy Reviews 2012, 16(5), 2781-2805.

4. Arlabosse, P.; Ferrasse, J.-H.; Lecomte, D.; Crine, M.; Dumont, Y.; Léonard, A. Efficient Sludge Thermal Processing : From Drying to Thermal Valorization, Modern Drying Technology. 2012, Wiley-VCH Verlag GmbH \& Co. KGaA, 295-329.

5. Chen, G.H.; Yue, P.L.; Mujumdar, A.S. Sludge dewatering and drying. Drying Technology 2002, 20(4-5), 883-916.

6. Tuncal, T.; Jangam, S.V.; Gunes, E. Abatement of Organic Pollutant Concentrations in Residual Treatment Sludges: A Review of Selected Treatment Technologies Including Drying. Drying Technology 2011, 29(14), 1601-1610.

7. Bennamoun, L.; Arlabosse, P.; Leonard, A. Review on fundamental aspect of application of drying process to wastewater sludge. Renewable \& Sustainable Energy Reviews 2013, 28, 29-43.

8. Chabrier, J.-P. Le séchage thermique des boues : Le développement, ses avantages et ses inconvénients. Journée technique du SIAAP (In French). 2007. 
9. European committee for standardization. Characterization of sludges. Good practice for sludges drying, PD CEN/TR 15473. 2007.

10. Arlabosse, P.; Chitu, T. Identification of the Limiting Mechanism in Contact Drying of Agitated Sewage Sludge. Drying Technology 2007, 25(4), 557-567.

11. Yan, J.-H.; Deng, W.-Y.; Li, X.-D.; Wang, F.; Chi, Y.; Lu, S.-Y.; Cen, K.-F. Experimental and theoretical study of agitated contact drying of sewage sludge under partial vacuum conditions. Drying Technology 2009, 27(6), 787-796.

12. Deng, W.-Y.; Yan, J.-H.; Li, X.-D.; Wang, F.; Lu, S.-Y.; Chi, Y.; Cen, K.-F. Measurement and simulation of the contact drying of sewage sludge in a Nara-type paddle dryer. Chemical Engineering Science 2009, 64(24), 5117-5124.

13. Tazaki, M.; Tsuno, H.; Takaoka, M.; Shimizu, K. Modeling of sludge behavior in a steam dryer. Drying Technology 2011, 29(14), 1748-1757.

14. Charlou, C.; Sauceau, M.; Arlabosse, P. Characterisation of Residence Time Distribution in a Continuous Paddle Dryer. Journal of Residuals Science \& Technology 2013, $10(3), 117-125$.

15. Seyssiecq, I.; Ferrasse, J.-H.; Roche, N. State-of-the-art: rheological characterisation of wastewater treatment sludge. Biochemical Engineering Journal 2003, $16(1), 41-56$.

16. Ratkovich, N.; Horn, W.; Helmus, F.P.; Rosenberger, S.; Naessens, W.; Nopens, I.; Bentzen, T.R. Activated sludge rheology : a critical review on data collection and modelling. Water Research 2013, 47(2), 463-482. 
17. Eshtiaghi, N.; Markis, F.; Yap, S.D.; Baudez, J.-C.; Slatter, P. Rheological characterisation of municipal sludge : a review. Water Research 2013, 47(15), 54935510.

18. Danckwerts, P.V. Continuous flow systems : distribution of residence times. Chemical Engineering Science 1953, 2(1), 1-13.

19. Levenspiel, O. Chemical reaction engineering. 1999: Hardcover. 688.

20. Gao, Y.; Muzzio, F.J.; Lerapetritou, M.G. A review of the residence time distribution (RTD) applications in solid unit operations. Powder Technology 2012, $228(0), 416-423$.

21. Berthiaux, H.; Mizonov, V. Applications of Markov chains in particulate process engineering: A review. Canadian Journal of Chemical Engineering 2004, 82(6), 11431168.

22. Harris, A.T.; Thorpe, R.B.; Davidson, J.F. Stochastic modelling of the particle residence time distribution in circulating fluidised bed risers. Chemical Engineering Science 2002, 57(22-23), 4779-4796.

23. Berthiaux, H.; Mizonov, V.; Zhukov, V. Application of the theory of Markov chains to model different processes in particle technology. Powder Technology 2005, 157(1-3), 128-137.

24. Marikh, K.; Berthiaux, H.; Mizonov, V.; Barantseva, E.; Ponomarev, D. Flow analysis and markov chain modelling to quantify the agitation effect in a continuous powder mixer. Chemical Engineering Research and Design 2006, 84(11), 1059-1074. 25. Ponomarev, D.; Rodier, E.; Sauceau, M.; Nikitine, C.m.; Mizonov, V.; Fages, J. Modelling non-homogeneous flow and residence time distribution in a single-screw 
extruder by means of Markov chains. Journal of Mathematical Chemistry 2012, 50(8), 2141-2154.

26. Mizonov, V.; Berthiaux, H.; Arlabosse, P.; Djerroud, D. Application of the theory of Markov chains to model heat and mass transfer between stochastically moving particulate and gas flows. Granular Matter 2008, 10(4), 335-340.

27. Mizonov, V.; Zaitsev, V.; Volynskii, V.; Leznov, V. Modeling the moisture content distribution over a rotating porous cylinder using Markov chains. Chemical Engineering \& Technology 2008, 34(7), 1185-1190.

28. Tamir, A. Chapter 2 - Fundamentals of Markov chains, Applications of Markov chains in chemical engineering. 1998, Elsevier Science B.V: Amsterdam, 11-185.

29. Charlou, C.; Milhe, M.; Sauceau, M., Arlabosse, P. A new methodology for measurement of sludge residence time distribution in a paddle dryer using X-ray fluorescence analysis. Water Reseach (under review). 
Table 1. Geometric residence time and transition probabilities in each cell

\begin{tabular}{|c|c|c|c|c|}
\hline Cell & $i=1$ & $1<\mathrm{i}<\mathrm{n}$ & $\mathrm{i}=\mathrm{n}$ & $i=n+1$ \\
\hline$\tau_{\text {cell }}$ & $\frac{H u}{1+R Q_{d s}}$ & $\frac{H u}{1+2 R Q_{d s}}$ & $\frac{H u}{1+R Q_{d s}}$ & 0 \\
\hline $\mathbf{P}_{\mathrm{i}, \mathrm{i}}$ & $e^{-\frac{\Delta t}{\tau_{1}}}$ & $e^{-\frac{\Delta t}{\tau_{i}}}$ & $e^{-\frac{\Delta t}{\tau_{n}}}$ & 1 \\
\hline $\mathbf{P}_{\mathrm{i}-1, \mathrm{i}}$ & 0 & $\frac{R}{1+2 R} 1-P_{i, i}$ & $\frac{1}{1+R} 1-P_{n, n}$ & \\
\hline $\mathbf{P}_{\mathrm{i}+1, \mathrm{i}}$ & $1-P_{11}$ & $\frac{1+R}{1+2 R} 1-P_{i, i}$ & $\frac{R}{1+R}$ & 0 \\
\hline
\end{tabular}


Table 2. Experimental and calculated parameters from RTD curves in Figure 5

\begin{tabular}{|c|c|c|c|c|c|}
\hline Parameter & $\overline{t_{s}(\mathrm{~h})}$ & $\sigma^{2}\left(h^{2}\right)$ & $H u(\mathrm{~g})$ & $R(-)$ & Stirrer speed \\
\hline Experimental & 1.3 & 0.9 & 33.2 & $(-)$ & $28 \mathrm{rpm}$ \\
\hline Optimized & $1.2 \pm 0.1$ & $0.6 \pm 0.1$ & $31.4 \pm 1.7$ & $4.5 \pm 1.2$ & \\
\hline Experimental & 1.3 & 0.6 & 31.6 & $(-)$ & $14 \mathrm{rpm}$ \\
\hline Optimized & $1.3 \pm 0.1$ & $0.5 \pm 0.1$ & $33.2 \pm 1.4$ & $3.3 \pm 0.7$ & \\
\hline
\end{tabular}


Figure 1. Schematic representation of the lab-scale paddle dryer and photo of the mixing device.
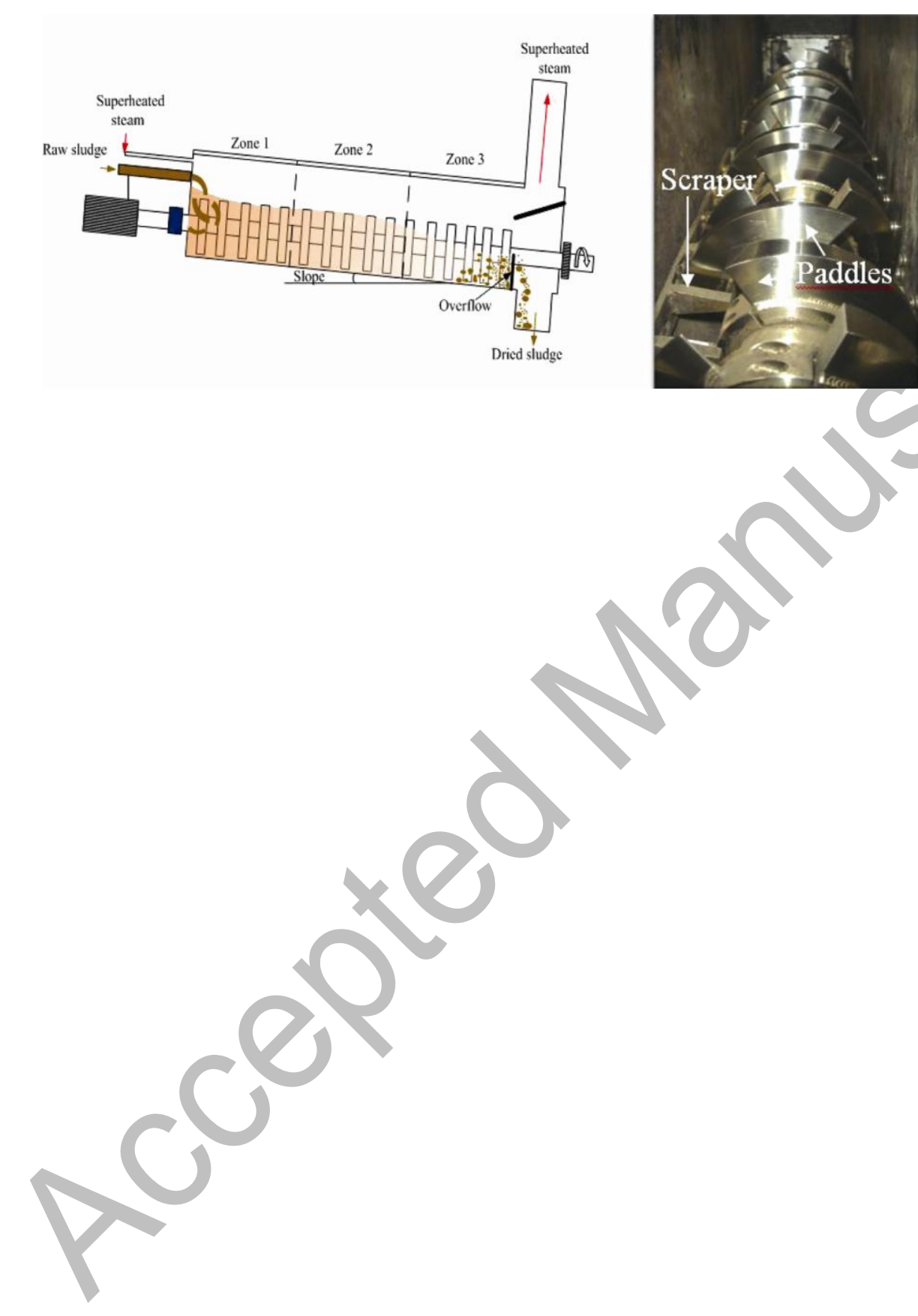
Figure 2. 1D cells chain for the modelling of solids flow in a paddle dryer.

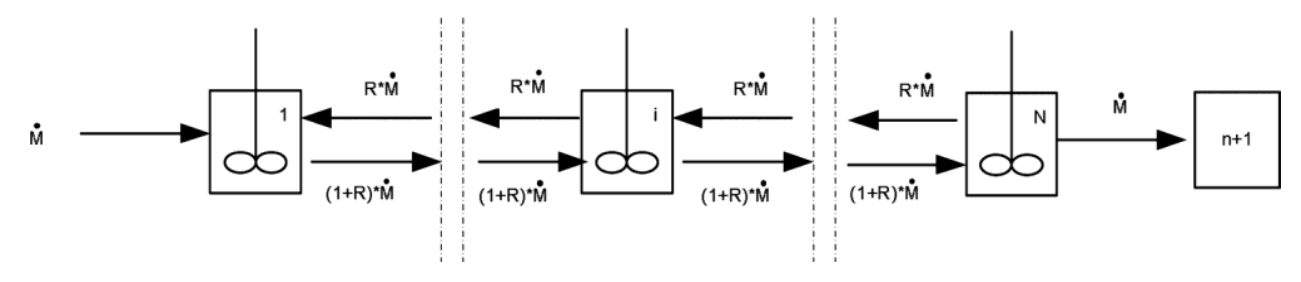


Figure 3. Influence of the transition duration, $\Delta t$, on the mean residence time and the dimensionless variance, standardized by the results for $\Delta t=0.5 \mathrm{~s}$, for $R=1.9$ and $\xi=0.19 \mathrm{~h}$ (dot) or $R=4.6$ and $\xi=0.16 \mathrm{~h}$ (square).
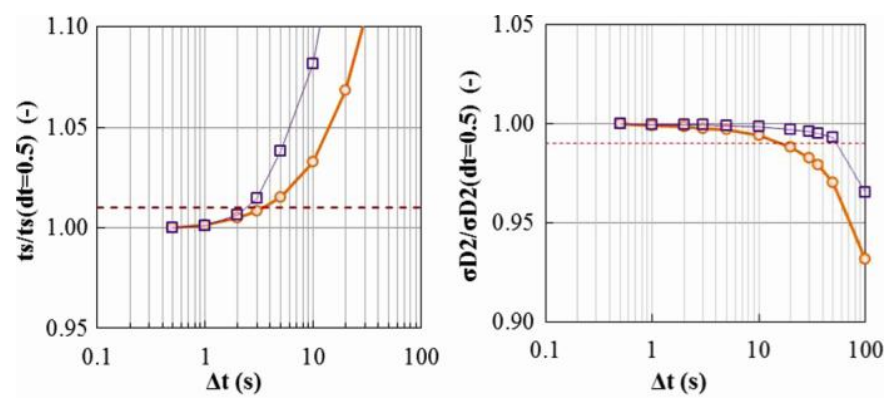
Figure 4. Influence of the transition duration, $\Delta t$, on the exit age distribution function, $E(t)$, for $R=4$ and $\xi=0.1 \mathrm{~h}$.

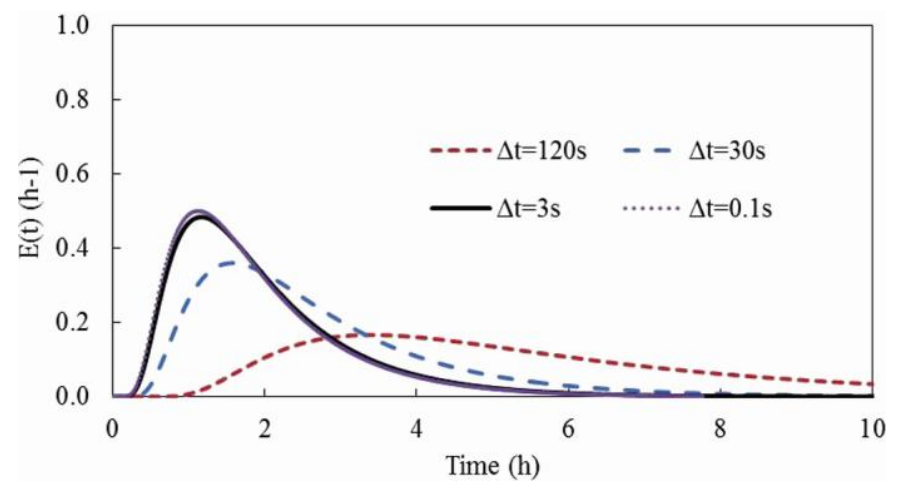


Figure 5-Comparison of experimental and computed RTD functions for a pulse injection of tracer in steady-state operation (only one tracer is represented): (a) stirring speed of $28 \mathrm{rpm}$; (b) stirring speed of $14 \mathrm{rpm}$.

(a) $28 \mathrm{rpm}$

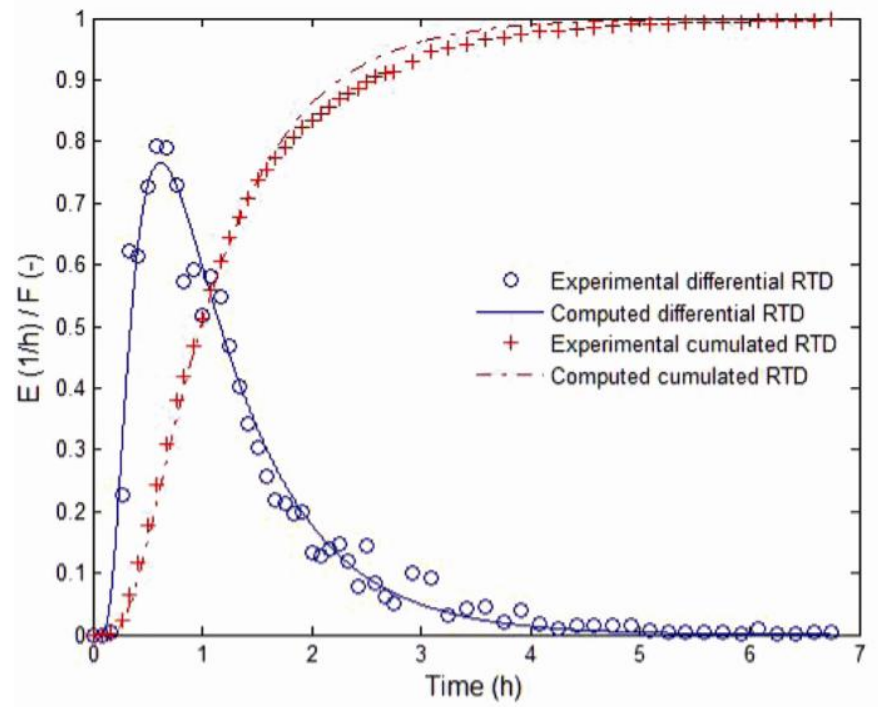

(b) $14 \mathrm{rpm}$

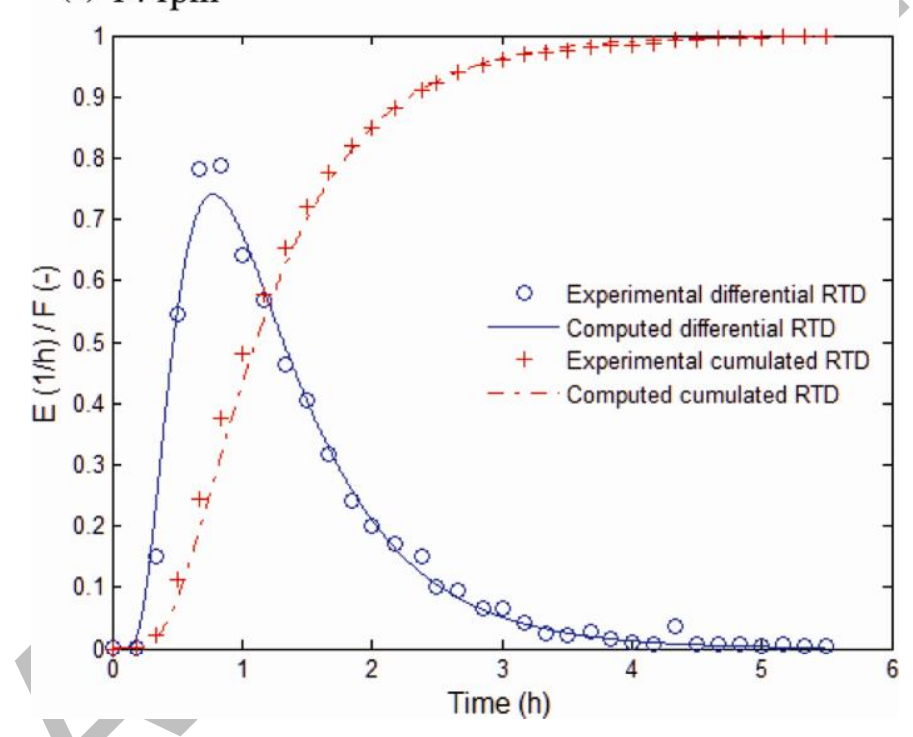


Figure 6. Influence of the recirculation coefficient $R$ on the exit age distribution function $E(t)$ for $\xi=0.1 \mathrm{~h}$.

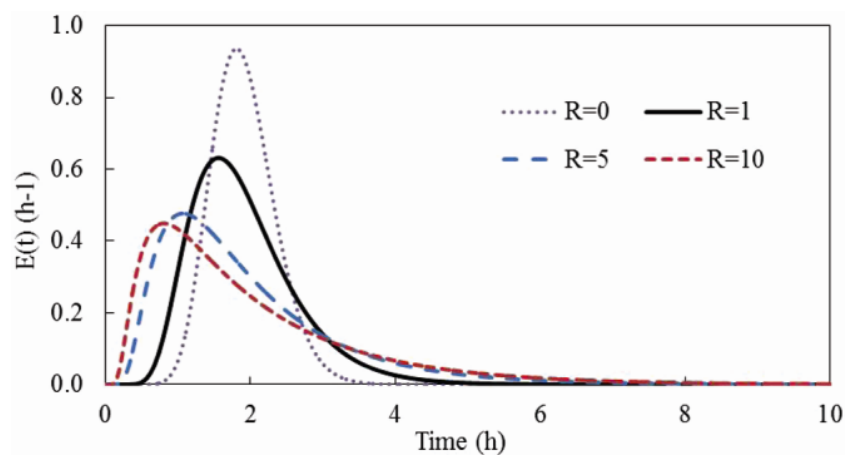


Figure 7. Influence of the ratio $\xi$ on the exit age distribution function $E(t)$ for $R=4$.

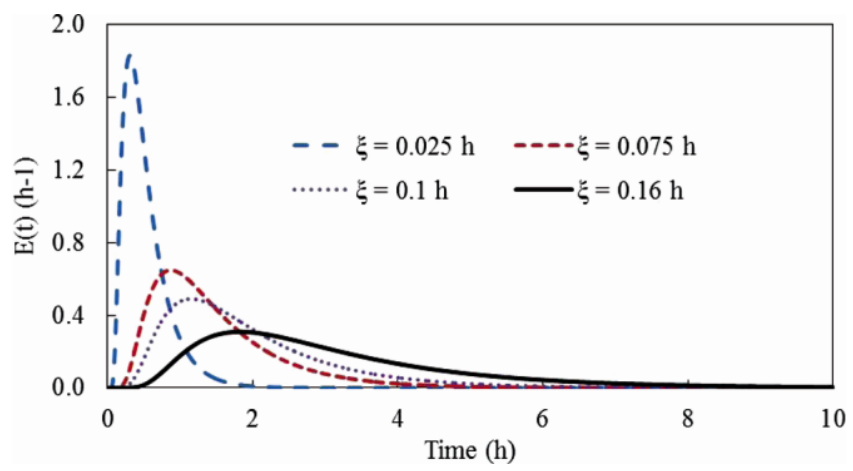


Figure 8. Influence of the recirculation coefficient $R$ on the mean residence time (left) and the dimensionless variance (right) for different values of the ratio $\xi$.
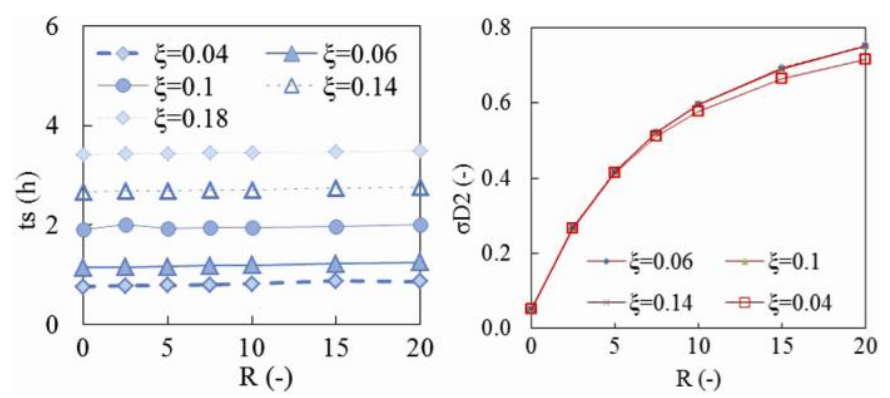